\title{
MANTENDO PRÁTICAS NÃO-RACIONALIZADAS: CORPO-MENTE, PODER E ÉTICA SITUACIONAL: UMA ENTREVISTA COM HUBERT \& STUART DREYFUS ${ }^{1}$
}

\author{
Bent FLYVBJERG ${ }^{2}$ \\ Tradução do inglês: Álvaro L. HATTHER ${ }^{3}$ \\ Revisão Especializada: Maria E. O. Gonzales ${ }^{4}$
}

Quando eu estava em Frankfurt e apresentei o modelo de habilidades em cinco estágios, Habermas disse, 'Você está falando sobre habilidades como martelar e jogar xadrez, mas o que você realmente quer fazer é enfraquecer a sociedade ocidental'. Eu disse 'Você está certo, esse é exatamente o meu objetivo'.

Hubert Dreyfus

\section{Hubert \& Stuart Dreyfus}

Ao examinar uma grande variedade de habilidades tão diferentes quanto dirigir um carro ou jogar xadrez, os Dreyfus descobriram que há um padrão comum associado ao aperfeiçoamento de habilidades, que pode ser esquematizado em uma seqüência de desenvolvimento. Há cinco estágios cuja ordem de ocorrência é invariável: aprendiz, principiante avançado, competência, proficiência e perícia.

\footnotetext{
1. A maior parte desta entrevista foi feita em maio de 1989 e junho de 1990 em três encontros, dois com Hubert e Stuart Dreyfus e um com Hubert Dreyfus. O material dessas três entrevistas foi complementado com material de outras duas, realizadas em 1987, uma com Hubert Dreyfus e a outra com Stuart Dreyfus. Todas elas foram realizadas na University of California, Berkeley. A pesquisa para as entrevistas recebeu o apoio do Conselho Dinamarquês de Pesquisa em Ciência Social e do Conselho Nacional de Pesquisa da Dinamarca. Neal Richman, Research Fellow na University of Aalborg, auxiliou na edição da entrevista.

2. Departamento de Desenvolvimento e Planejamento da Universidade de Aalborg.

3. Oficina de Tradução do IBILCE - Instituto de Biociências, Letras e Ciências Exatas - UNESP - 15054-000 - São José do Rio Preto - SP. Colaboraram na tradução: Alexandrina A. L. de Oliveira, Elaine Ap. Vieira, Maria Paula P. Vianna (Oficina de Tradução, UNESP - S.J. do Rio Preto).

4. Departamento de Filosofia - Faculdade de Filosofia e Ciências - UNESP - 17525-900 - Marília - SP.
} 
Os aprendizes buscam traços independentes de contexto os quais interpretam com base em regras. Motoristas novatos olham para o painel do carro para verificar a velocidade ou as rotações do motor e seguem regras para troca de marchas. Enxadristas novatos avaliam suas peças por valor numérico e aplicam a regra "Sempre troque se o valor total das peças capturadas exceder o valor das peças perdidas". À medida que adquire experiência, o principiante avançado pode começar a selecionar "dicas" situacionais, tais como o som que o carro faz quando a marcha precisa ser mudada ou a ocorrência de uma "lateral desprotegida do rei" ou de uma "forte estrutura de peões ". As máximas baseadas na capacidade de se reconhecer tais dicas situacionais servem, então, para instruir o indivíduo a mudar a marcha em resposta a um "som de motor acelerado" ou a atacar a lateral desprotegida do rei.

Ao nível da competência, pode-se organizar uma grande quantidade de dados a respeito de uma situação por meio de categorização. Dessa forma, podem-se focalizar pontos específicos que requeiram atenção transformando-os em pontos de destaque colocados contra um entendimento de base da situação como um todo. A ação é o produto de deliberação concentrada sobre alternativas à luz dos pontos de destaque; e um ulterior envolvimento emocional com o resultado é o subproduto de um fluxo de ação que é sentido como produzindo o julgamento individual. Um motorista competente, que se percebe fazendo uma curva em uma estrada escorregadia em alta velocidade, escolhe cautelosamente se deve pisar no freio ou apenas tirar o pé do acelerador. Ele experimenta o resultado de sua escolha de forma mais pessoal do que um principiante. Um enxadrista competente reconhece um rei desprotegido como sendo a situação de destaque a seu alcance e planeja seu ataque sem se distrair com quaisquer outras características do tabuleiro ou com conseqüências que são secundárias a seu plano de ação.

Ao nível da proficiência não há momento de imparcialidade no qual uma situação seja avaliada e categorizada. O "encanto do envolvimento" não é quebrado, mas, ao invés disso, há a perplexidade pelo tipo de situação em que se encontra. Entretanto, o encanto é quebrado no momento de se selecionar uma resposta, que se torna sujeita à ponderação.

Por fim, quando se atinge a perícia, pode-se imediatamente perceber a natureza da situação e "saber" o que precisa ser feito. O motorista perito percebe quando é necessário diminuir a velocidade e "sabe" como executar a ação sem calcular e comparar as alternativas. O enxadrista perito, considerado um mestre ou grão-mestre internacional, geralmente pode jogar de forma a não admitir a possibilidade de análise e comparação de alternativas. A capacidade do perito em xadrez de jogar por intuição é demonstrada por uma experiência conduzida pelos Dreyfus na qual contavam com um mestre internacional jogando uma partida extremamente rápida ao mesmo tempo que rapidamente somava números. Ele ainda era capaz de "se agüentar" contra um jogador de mesmo nível, ainda que obviamente privado de qualquer oportunidade de ponderação. 
P: Conceitos como corpo, poder e ética têm ocupado um lugar fundamental na obra de Hubert Dreyfus, em especial em relação a Foucalt, Heidegger e Merleau-Ponty. Estou impressionado pela ausência virtual desses conceitos em sua obra sobre aprendizagem. Vamos falar sobre o corpo primeiro. Você fez um relato bastante abrangente do modelo de cinco estágios de aprendizagem em Mind Over Machine (1988). No título do livro e em suas afirmações gerais sobre aprendizagem, a mente é enfatizada. Contudo, parece-me que muitos exemplos que você e Stuart fornecem dependem de aprendizagem física, ainda que vocês não tenham afirmado isso de maneira explícita. Nos últimos anos tem surgido a discussão sobre o papel do corpo na filosofia e na reflexão social. Como o corpo entra em seu modelo de aprendizagem e como isso se relaciona com a antiga divisão entre corpo e mente no pensamento ocidental?

HD: Mind Over Machine não era o nosso título, pois, o corpo é tão importante quanto a mente. Nossa idéia ultrapassa essa distinção. É por isso que falamos muito sobre xadrez e dirigir veículos. O xadrez é uma habilidade mental, enquanto dirigir um carro é uma habilidade corporal. E, conforme dissemos, você passa pelos mesmos cinco estágios em qualquer uma dessas habilidades. Pode-se pensar que a habilidade holística de fazer coisas de maneira intuitiva está, basicamente, no corpo. Mas não creio que isso seja correto, porque o xadrez é uma atividade bastante desincorporada. Assim, a habilidade parece ultrapassar a distinção corpo/mente e o título enganador do livro é muito infeliz. Deveria ser algo como Body-Mind Over Machine.

P: A intuição é fundamental em seu modelo. Onde reside a intuição no que você caracterizou de corpo-mente?

HD: Acredito que haveria uma tendência a se pensar no corpo. Meu filósofo favorito é Merleau-Ponty, que escreve sobre as habilidades corporais e o corpo holístico promovendo a gestalt do mundo. Mas parece-me claro que seria impossível pensar que a intuição no xadrez tenha algo a ver com o corpo. A intuição não está presente no corpo ou na mente. Na verdade, ela reside no fato de o cérebro poder armazenar gestalts inteiros. O xadrez é um exemplo perfeito, porque você não precisa nem mesmo de percepção. Uma pessoa cega pode tornar-se um mestre no xadrez. É uma atividade totalmente mental. A distinção entre corpo e mente é importante pelo fato de que a mente pode ser analítica, sendo, portanto, contrária ao corpo, pois não creio que este possa ser analítico. Assim, se há algum problema é sempre a mente que o causa. Se você não se torna intuitivo, deve ser porque a mente se interpôs. Mas se você se torna intuitivo, isso não acontece porque a mente deixou de se interpor e permite ao corpo fazer as coisas. Parece-me que é porque a mente analítica deixou de se interpor e permitiu que a mente intuitiva atuasse. 
P: Quando é que um jogador de xadrez sente que um movimento está certo? Qual é a sensação e onde está localizada, se é que está localizada?

SD: No corpo inteiro. Na boca do estômago. Isso é igual a perguntar onde você sente que está com fome, quando está com fome. Você não pode dizer que é seu cérebro que pensa que está com fome. Você vivencia seu corpo todo com desejo e o jogador de xadrez tem o mesmo tipo de experiência. Como pode ver, eu discordo de Hubert. Quando um jogador de xadrez faz uma jogada em um segundo, o que é realmente uma jogada rápida, eu os tenho ouvido descrever uma sensação engraçada de que a mão é que joga e não eles. Eles falam desse jeito. A mão deles está apenas movimentando as peças tão rapidamente, e eles quase sentem como se seu cérebro, separado, olhasse suas mãos jogarem xadrez. Portanto, o corpo todo está nesse quadro.

HD: O que entra no xadrez são as emoções. Você tem que se envolver no jogo. Tem que se interessar por ele. Mas não sei exatamente onde as emoções estão corporificadas. Elas não podem estar na mente entendida como mente analítica e objetiva separada, que é o modo Cartesiano mais comum de compreender a mente.

SD: Basicamente, meu trabalho está me levando a rejeitar a divisão entre mente e corpo. Essa divisão causou muitos problemas para a cultura ocidental e nos levou a acreditar em racionalidade e coisas semelhantes. Meu trabalho com redes neurais e conexionismo está me levando a perceber muito sobre o comportamento hábil como uma atividade na qual não há qualquer papel para a mente da forma como é geralmente definida. Tudo é "corpo", se pensarmos nos neurônios como sendo parte do corpo e não da mente.

P: O que significa, mais especificamente, "neurônios sendo parte do corpo e não da mente"?

SD: A tradição acha que a mente é uma coisa separada. Ela situa-se num plano separado do mundo, que observa e pensa sobre o mundo. A tradição julga que o corpo está sempre no mundo. Você não pode separar seu corpo do mundo, mas pode separar sua mente, e, portanto, a concepção tradicional de corpo/mente exige que se veja uma mente separada manipulando um corpo no mundo. Em oposição a isto, a concepção conexionista vê a mente de um especialista tão envolvida quanto o corpo. Ambos atuam sobre estímulos que vêm do mundo, sem qualquer grau de interpretação. Outra maneira de dizer isso é que a noção comum de mente considera o que chega aos sentidos como dados brutos e vê a mente como interpretando esses dados por meio da manipulação de suas representações. O ponto de vista conexionista é o de que a mente de um especialista não faz isto, e se você fizer, não será um 
especialista. Você apenas tem que reagir aos estímulos. Os neurônios no cérebro produzem uma resposta quando os estímulos ocorrem de determinada maneira. Trata-se de uma interpretação muito mais física.

P: Além do corpo, poder e ética são os conceitos que me parecem essenciais para uma compreensão das habilidades e do processo de incapacidade, isto é, pessoas que perdem a capacidade e a intuição para processos de trabalho mecanizado. Por que você não enfatiza esses conceitos em sua obra sobre aprendizagem?

HD: Fomos constantemente forçados a falar sobre ética e política de conhecimento implícito por Tom Athanasiou, que estava nos ajudando a escrever Mind Over Machine. Nossa norma sempre foi a de falarmos sobre o que sabemos, e pelo menos uma coisa ficou clara: se você não entende o que é habilidade e conhecimento implícito, não pode nem mesmo discutir, de um modo inteligente, questões sobre movimento trabalhista, social e político, questões relacionadas a poder etc. Perde-se tempo com a preocupação sobre o que fazer se os computadores e os sistemas especializados substituírem peritos e trabalhadores, quando esse não é o verdadeiro problema, pois eles não podem fazer isso. Portanto, não falamos sobre os problemas sociais. Presumo que haverá um tipo de Taylorismo semelhante à descrição de Foucault sobre corpos dóceis que seria a ciência do comportamento eficiente. Alguém tentaria disciplinar as habilidades especializadas. Pelo que sei, Foucault não fala sobre um ponto importante: que os corpos disciplinados não serão bons para fazerem o que fazem, sendo intuitivos. Eles podem ser bons em outras coisas, sendo mais organizados, seguros, controláveis, e mesmo mais intensos em sentido social, mas não serão tão habilidosos. Os sindicatos sabem disso. Há poder no conhecimento implícito dos trabalhadores ou das pessoas capazes, que a relação poder/conhecimento não consegue controlar.

\section{P: Seria possível haver uma ciência dessas habilidades?}

HD: Não, é exatamente por isso que poder e conhecimento não podem controlar as habilidades. Você não pode ter uma ciência dessas habilidades e, portanto, elas são um tipo de poder contrário. É a isso que Foucault se refere quando fala sobre conhecimento marginalizado, o conhecimento dos marginalizados dispersos. Acho que há um conhecimento que qualquer pessoa que seja habilitada em alguma coisa tem, e que é externo a todo o complexo de ciência e poder. Os sindicatos da Suécia refletem sobre o que é o conhecimento implícito e como preservá-lo e ampliá-lo.

P: Se ampliarmos essa questão das habilidades para abranger as práticas humanas em geral, parece-me que aquilo que você acabou de descrever acerca dos trabalhadores corresponde de perto, a um conceito ao qual você se referiu resumida- 
mente em diversos contextos, isto é, o conceito das assim chamadas práticas marginais ou não-racionalizadas. Você poderia expandir esse conceito?

HD: Atualmente, o exemplo favorito parece ser a amizade. As pessoas têm várias formas de apoiar, escolher e abandonar seus amigos, mas a filosofia não as estuda nem tenta criar princípios a esse respeito, sendo que isso não se tornou parte da ordenação tecnológica eficaz das coisas. As pessoas não saem dizendo que deveríamos tornar a amizade mais eficaz, mais produtiva e assim por diante, portanto ela existe como um tipo de prática não-racionalizada.

P: Você poderia mencionar outros domínios das práticas marginais ou nãoracionalizadas?

HD: Meus outros dois exemplos favoritos são a enfermagem e o ensino. Há um livro chamado The Primacy of Caring [A Primazia do Atendimento], escrito por uma enfermeira que costumava freqüentar os nossos cursos sobre Heidegger e Kierkegaard. Nesse livro ela mostra que cuidar das pessoas é uma prática que as enfermeiras têm e que todos temos porque a herdamos do Cristianismo (Benner, 1989). Mas não é uma prática racionalizada no sentido de que não a fazemos sobre princípios e nem tentamos organizá-la no interesse da eficiência. É um tipo de prática que ela acredita não poder ser organizada em termos de eficiência. Ela acha que as enfermeiras a têm e os médicos tendem a não ter. Eles querem apenas deixar as pessoas saudáveis e produtivas, mas não querem ter que cuidar delas. Na verdade, ela acha que se você não cuida das pessoas, não pode tratá-las muito bem medicamente.

Existem pessoas em nossa cultura que se tornam professores secundários, alguns deles porque é o único emprego que conseguem, mas, outros, suponho que seja porque, para eles, não há nada mais importante que educar os jovens e as pessoas. É outro tipo de prática, neste caso, herdada dos gregos. Penso no cuidar como uma prática cristã marginal que já foi fundamental e hoje não é mais, porque o Cristianismo não é mais uma parte viva do que Hegel chamou nossa sittlichkeit, nossos costumes e práticas sociais compartilhados; pelo menos não é a parte fundamental deles. As práticas ligadas à educação eram a coisa mais importante para os gregos, pelo menos para as pessoas ao redor de Platão e Sócrates. Hoje, entretanto, elas não têm mais a importância institucional que possuíam naquela época. Ora, não se ganha qualquer reconhecimento por ser professor secundário, não se ganha muito dinheiro nem muito prestígio. Então, por que algumas pessoas fazem isso se são inteligentes o bastante para fazerem qualquer outra coisa? Se realmente existem pessoas que fazem isto, muito embora sejam inteligentes e trabalhadoras o bastante para fazerem algo diferente, deve ser porque é importante para elas e essa importância deve ser do tipo marginal. 
P: Não se poderia dizer que o que está acontecendo com a amizade, cuidado etc., na sociedade moderna, é exatamente que estão sendo racionalizados? Por exemplo, se você quiser ter sucesso no mundo acadêmico ou empresarial pode ser importante ter os amigos certos e as pessoas podem passar a escolher amigos fundamentalmente nessas bases.

HD: As práticas marginais sempre correm o risco de serem assumidas pela compreensão racional e tecnológica e tornadas eficazes e produtivas. Acho que foi minha ex-aluna, Jane Rubin, que me contou que ouviu uma propaganda no rádio dizendo que ter amigos é saudável. No momento em que você tem amigos para sua saúde e sua carreira, você tem um tipo de amizade que é do tipo racional-tecnológico. Isto sempre pode acontecer, e suponho que este novo tipo de amizade poderia substituir um outro tipo de amizade. As pessoas nem saberiam mais o que seria uma verdadeira amizade. Isto é perigoso e é por isso que é necessário fortalecer o que chamo de práticas em extinção. Penso que Heidegger e Foucault também acreditam nisso.

O amor romântico que Kierkegaard estava tentando salvar é outra dessas práticas. E, por falar nisso, o mesmo se dá com os direitos dos animais. Há pouco tempo muitos ativistas dos direitos dos animais invadiram um prédio e entraram em conflito com a polícia da universidade [a Universidade da Califórnia, Berkeley]. Primeiro, pensei, "ah, mais fanáticos loucos", mas depois percebi, não, essas pessoas representam uma versão de outro tipo de prática marginal, alguém que se sente em comunhão com os animais e não pensa que estes sejam tão diferentes dos seres humanos que possam ser sacrificados e sofrer para nos tornar mais saudáveis e para que vivamos mais. Todas essas práticas deveriam ser preservadas e deveriam estar constantemente em pauta, para questionar a hegemonia, como dizem as pessoas atualmente, sobre eficiência humana, produtividade, saúde e bem-estar.

P: Como se pode defender essas práticas marginais, fortalecê-las e multiplicá-las para contrapor-se à racionalização?

HD: Não tenho a menor idéia. Heidegger diz que se deve preservar a força salvadora das coisas simples, mas não diz como fazer isso. Bob Dylan manda fortalecer as coisas que ficam. T. S. Eliot diz: sustentar os fragmentos contra nossa ruína. Os poetas falaram sobre essas coisas, mas, pelo que sei, ninguém fez nada a respeito. Acho que se pode dizer que não se deve tentar racionalizar e modernizá-las, nem se deve julgá-las como sendo triviais e insignificantes simplesmente porque não podem ser racionalizadas. Ao invés disso, seria melhor praticar tantas vezes quanto parecesse natural, e não se preocupar com o fato de que, no domínio vigente da compreensão da realidade, elas parecem ser, no máximo, triviais, e, no mínimo, contraproducentes. Ou seja, pode parecer que você tenha perdido seu tempo fazendo alguma coisa para 
se aperfeiçoar e aí está você, brincando com seus filhos, conversando com os amigos ou acariciando os animais e olhando em seus olhos. Algumas pessoas poderiam dizer que você está perdendo seu tempo, que você não está tirando o melhor da vida, mas você deve resistir a isso.

P: Você falou sobre os poetas. Há um papel para o filósofo profissional e para o pensador social nesse tipo de questão?

HD: Suponho que não, se por filósofos profissionais você entender pessoas na linha de Platão, via Kant a té Habermas. Mas as pessoas nos departamentos de filosofia poderiam escrever livros como The Primacy of Caring, que ocorreu de ter sido escrito por uma professora de enfermagem, mas que foi muito influenciada por filósofos. Presumo que alguém poderia escrever um livro sobre amizade que fosse o tipo errado de livro, pois teria perguntas tais como "quais as condições necessárias e suficientes para confiar em alguém como amigo?", ou "quais os princípios fundamentais que dizem o que se deve fazer com os amigos?", o que seria terrível. Mas pode-se escrever um livro de filosofia que descreva a prática da amizade ao longo da história ou mesmo da forma como se manifesta hoje. Os filósofos não se preocupam em escrever livros desse tipo. Zen and the Art of Motorcycle Maintenance é um livro que não foi escrito por filósofo $(1974,1984)$. A coisa mais próxima de um livro como esse, escrito por um filósofo em um departamento de filosofia é Technology and The Character of Contemporary Life por Albert Borgmann (1984). Ele fala sobre práticas focais, que é o nome que dá para uma subclasse das práticas marginais. Ele vê como a tecnologia dispersa e destrói essas práticas, porque a tecnologia facilita a obtenção de resultados sem qualquer esforço e focalização. Por exemplo, para ouvir música você pode simplesmente ligar um aparelho de som. Borgmann contrasta isto com o aprendizado de um instrumento, juntando pessoas, praticando, e, por fim, tocando em grupo. Isto foi uma conquista focal, colocar todas essas pessoas e coisas juntas. É como Heidegger falando sobre as pessoas sentadas em círculo com uma jarra de vinho. Borgmann diz que você tem de resistir à maneira pela qual a tecnologia lhe dá o resultado sem qualquer esforço, porque dessa forma você não terá a experiência focal. Isto é muito interessante. Outra prática, para ele, é a refeição familiar. Toda a família reunida para um jantar que todos realmente ajudaram a preparar, e não cada um deles comendo a própria refeição numa bandeja diante da televisão em cômodos separados. Estamos perdendo esta prática focal. Graças à tecnologia e à comida congelada, as pessoas não têm mais que prepará-las, nem comê-las no mesmo horário.

P: Você está dando exemplos de como podemos agir individualmente contra a racionalização. Na Escandinávia fomos acostumados a questionar, além disso, o que pode ser feito ao nível social, coletiva e politicamente? 
HD: Meus exemplos não se referem apenas ao que podemos fazer como indivíduos mas também como grupo: dois amigos, uma família ou quatro pessoas. Mas você está querendo algo maior. O que você realmente deseja saber, na condição de escandinavo, é como as práticas de salvamento podem ser legisladas. Sua pergunta é tipicamente escandinava, é fascinante e intrigante. Se são tão boas para todos, queremos preservá-las, então devemos ter algum tipo de movimento político e criar leis que as preservem. Não consigo imaginar com o que isso iria se parecer, leis que preservassem a amizade, o carinho, o ato de educar, as refeições familiares e pessoas tocando música juntas, ou mesmo leis que evitassem as formas pelas quais essas coisas estão sendo corroídas. Pelo menos podemos anular o que está pondo essas práticas em perigo, o que seria uma idéia escandinava. Não vejo como, já que o que está pondo essas práticas em perigo não é algo que se possa anular, é racionalidade, eficiência. Quero dizer, por que deveríamos tocar música juntos se cada um de nós pode ligar um aparelho de som? Por que perder tempo com amigos - com o que costumávamos chamar de amigos - se você pode jogar golfe com o chefe da empresa? Isso é fascinante. Eu não sei de que lado você está quando faz esta pergunta como um escandinavo, mas eu diria que é onde o verdadeiro problema reside, no caso da abordagem escandinava. Faz parte da postura de racionalização pensar que se pode legislar sobre tudo o que seja valioso.

P: Por outro lado, muitas pessoas podem achar um tanto desesperador não poder fazer algo maior, coletivamente, no que diz respeito àquilo que você vê como um problema maior, ou seja, a racionalização, não é mesmo?

HD: É verdade. Soa desesperador, e as pessoas acusam Heidegger e Foucault de serem versões diferentes de um tipo de pacifismo. Heidegger era explicitamente passivo. Ele dizia que não se pode fazer absolutamente nada organizado quanto à racionalização. Somente na sua própria vida você pode preservar as pequenas coisas e esperar que surja um novo paradigma que as tornará mais poderosas. Foucault era muito mais ativo e tentou lutar ao lado do conhecimento marginal. Você pode envolver-se naquilo em que ele estava envolvido, os direitos dos homossexuais e outras atividades desse tipo. Se você encontrar algum tipo de prática marginal contra a qual a lei esteja atuando, por exemplo, impedindo que antivivisseccionistas façam manifestações diante de laboratórios, então lute contra ela. Se você fosse Foucault, certamente gostaria de dizer que, se passasse por isso, se juntaria às pessoas que lutam pelos direitos dos animais. Você não zombaria delas porque não podem fornecer nenhuma base racional eficiente para o fato de pensarem que os animais são tão importantes quanto as pessoas, e você certamente não teria leis que agissem contra elas, dizendo que está escrito na Constituição que as pessoas têm direitos e os animais não, e, portanto, você não tem direito de lutar pelos animais. 
Mas isso ainda é muito pouco. Parece que não é o tipo de coisa que se possa buscar politicamente. Heidegger é explícito a esse respeito. Ele diz que no momento em que se tenta fazer da preservação das práticas marginais uma meta política, positiva, a tecnologia é trazida para a questão e destrói exatamente aquilo que se está tentando fazer. Eu nunca tinha entendido isso até que lhe contei a história sobre a Escandinávia, e agora entendo porque ele diz isso. Deseja-se legislar sobre a qualidade de vida e arranja-se um problema curioso, ou seja, os aspectos espontâneos, receptivos da qualidade de vida estariam perdidos se sobre ela incorresse alguma legislação. Felizmente há uma área intermediária onde há muito o que fazer. Isso mantém os escandinavos felizes e os torna interessantes. Quero dizer, você certamente poderia legislar contra não matar, por exemplo. As pessoas na Suécia se preocupam com isso. Esta é uma área em que algo deve ser feito.

P: Algumas pessoas, provavelmente incluindo Jürgen Habermas, considerariam essa atitude minimalista como conservadora e individualista.

HD: É verdade, Habermas realmente não gostaria disso. E Heidegger diria sobre pessoas como Habermas que elas pensam na tecnologia como uma prática que deveríamos controlar e usar para boas finalidades. Mas essa é uma maneira tecnológica de se pensar a este respeito, diria Heidegger. Para Foucault, é a universalidade de princípios subjacentes a tal tentativa que seria repugnante e perigosa, enquanto que para Heidegger é a tentativa de ganhar controle político sobre nossas vidas que seria o problema. Mas há um tipo de conservadorismo necessário nesta visão, em especial no sentido de conservar práticas que são marginais e antigas em nossa cultura. Mas eu não chamaria isso de conservadorismo, já que pode ser bastante radical, e você não parecerá conservador quando lutar por algumas dessas práticas.

P: Se voltarmos e olharmos para esta problemática das práticas racionalizadas versus as não-racionalizadas, com uma dimensão ligeiramente diferente daquela da política e da legislação, a saber, a da ética, pergunto-me: que tipo de ética estania implicada em sua posição? Parece-me que sua posição, incluindo o modo de aprendizagem em cinco estágios, é antitética em relação à busca da teoria, das regras e dos universais que estão na essência da maioria das obras sobre ética.

SD: Eu ministro um curso chamado "As Aplicações Sociais da Tecnologia". Ele é co-ministrado por vários professores. A primeira professora ensinou aos alunos as idéias filosóficas ocidentais tradicionais acerca de como tomar decisões éticas. Ela falou sobre utilitarismo, direitos, regras e princípios e disse à classe, basicamente, que, ao se tomar decisões sociais referentes à tecnologia, é preciso ter valores bem definidos e raciocinar a partir de preceitos primários. A tese da professora era a de que não se pode decidir racionalmente se o preceito primário A ou o preceito primário 
B é o certo, mas pode-se raciocinar a partir de qualquer uma dessas perspectivas. Ela estava ensinando a racionalidade no sentido de que pelo menos alguém deveria ser capaz de defender suas próprias conclusões, baseado em sua própria perspectiva.

Baseado no modelo de habilidades de cinco estágios, passei as três próximas conferências do curso tentando mostrar aos alunos que aquilo era perda de tempo. Em primeiro lugar, essa tese é polarizadora e não deixa nenhum espaço para discussão, e argumento se uma pessoa diz que meu preceito é A e portanto eu concluo $\mathrm{B}$, e uma outra disser que meus preceitos partem de $\mathrm{C}$ e portanto eu concluo D. Em segundo lugar, esse não é o modo como as pessoas realmente tomam decisões quando têm experiência em uma área. As decisões são tomadas com base em experiência prévia que se revelou ser boa ou ruim, bem ou malsucedida. Argumentei que não se deve tentar objetivar a questão, mas, ao contrário, discutir o precedente histórico de forma produtiva e não polarizadora. Isto é uma transformação total da questão do que seja comportamento ético ou moral partindo-se de uma visão baseada em princípios universais para uma outra baseada em história e narrativa.

\section{P: Você poderia me dar um exemplo disso?}

SD: Sim, só a estrutura da questão quanto ao que seja o problema já é meia resposta, e ninguém pensa que se pode definir racionalmente o que é o problema. Neste país, por exemplo, você pode ver o nosso maior problema como sendo a criminalidade ou você poderia vê-lo como sendo a pobreza. Se você vê o problema como pobreza, você diz que tratando da pobreza a criminalidade desaparecerá. Você vê a criminalidade como resultado do fato de existir uma classe empobrecida. Por outro lado, se você vê o problema como criminalidade, não se preocupa em cuidar do problema da pobreza. Tenta construir prisões e contratar mais policiais. Sua experiência dita o que você vê como problema. É somente o acúmulo da minha experiência de vida que me faz querer ver o problema como pobreza e não como criminalidade. Tenho certeza de que alguém que teve a experiência de um crime contra sua família o verá como criminalidade e não pobreza. Portanto percebe-se que a ética baseia-se na experiência e não no racional ou em um princípio.

\section{P: Você tem um nome para este tipo de ética?}

HD: Poderíamos chamá-la "ética situacional".

P: Embora historiadores da ciência argumentem convincentemente que o crescimento do pensamento científico não ocorre baseado em um grupo de princípios fixos, uma crença nos padrões universais tem um grande poder de permanência porque a alternativa gera o que Richard Bernstein chamou de "Ansiedade Cartesiana" - um sentimento de que a ciência poderia ser minada pelo subjetivismo e pela interprétação 
arbitránia. Como você responde à acusação de que a ética situacional está propensa a tal relativismo?

SD: A ética situacional certamente não me parece arbitrária. É, sem dúvida, subjetiva e interpretativa como uma função da nossa própria história pessoal, mas há espaço para se discutir se aquilo que mencionamos como sendo história relevante é realmente relevante. Se você for arbitrário dirá "Por causa desta experiência eu concluo isto e não vejo necessidade de defendê-lo". Eu acho que é necessário defender as interpretações que se tem baseadas em exemplos históricos e experiências.

HD: Mas ficará irredutivelmente subjetivo pelo fato de não haver resposta certa. Você poderia chegar ao ponto onde pessoas diferentes com experiências e pontos de vista diferentes, após terem discutido e discutido, veriam o problema cada uma à sua maneira.

SD: Os filósofos antigos sempre tentaram estabelecer sua visão daquilo que era certo.

HD: ...em alguma coisa: Deus, a natureza da racionalidade, a natureza do bom ou a natureza do organismo humano. E, para Habermas, na natureza da comunicação.

SD: É preciso reconhecer que é impossível basear nossas decisões morais nessa perspectiva. Não há escapatória a esse mal-estar, e o que estamos sugerindo é uma maneira mais sensível de se viver com ele.

P: Algum tempo atrás eu estava lendo a Ética a Nicômaco e estive pensando: como os conceitos aristotélicos techne e phronesis estão relacionados ao modelo de cinco estágios e à ética situacional?

HD: Phronesis é o nome que Aristóteles deu à sabedoria e experiência e nós nos consideramos aristotélicos. Aristóteles diz o seguinte, opondo-se a Platão: "Se você quer saber qual é a coisa certa a ser feita não procure princípios - consulte um homem velho e sábio." É isso o que pensamos também.

P: Em um trabalho recente (1988) você faz uma analogia entre techne e phronesis, considerando, ou assim me parece, phronesis como um caso de techne. Em minha interpretação, Anistóteles distingue os dois cuidadosamente e salienta a importância de não considerar phronesis como uma techne, como por exemplo no "Livro VI" da Ética a Nicômaco. Nele Aristóteles define techne como arte e ofício e phronesis como prudência ou sabedoria prática, enfatizando que phronesis é mais importante do que 
techne e episteme para o funcionamento de famílias e Estados. Feita esta interpretação, pergunto se é seguro considerar phronesis como techne?

HD: Sei que considero que techne e phronesis estão estreitamente relacionadas, e em seu trabalho elas são categonias muito diferentes. Eu sempre considerei techne apenas como habilidade, que é muitas vezes a maneira como é traduzida, e então phronesis seria apenas um caso de habilidade aplicada à vida cotidiana, em interações com pessoas na política, por exemplo. Mas se alguém as define a seu modo, então certamente elas estão separadas. Uma delas tem a ver com pessoas, a outra, com a maneira como as coisas são feitas. Entretanto, deve haver um outro nível de discussão. Eu não sei se é Aristóteles ou apenas eu, Stuart e Heidegger. Precisamos de uma noção de habilidade que seja intermediária a estas duas. Habilidade é o que você precisa para realizar sua arte e ofício, para fazer coisas a partir de coisas. E habilidade é o que você precisa para tratar com as outras pessoas e governar. Eu não sei qual seria a palavra para habilidade em grego, porque parece não haver palavras suficientes. Mas parece, de fato, que phronesis e techne são duas subcategorias de habilidade.

\section{P: É possível tratar as duas como uma, simplesmente como "habilidade"?}

HD: Não, e eu nunca disse isso. Eu as considerei em conjunto simplesmente porque, ao nível em que se tenta descrever o que é comportar-se habilmente em qualquer domínio, quer isto represente fazer alguma coisa, jogar xadrez ou ser uma pessoa ética, o nosso modelo de habilidade sustenta que se está respondendo a uma situação única. Isso não deve tornar iguais o ofício e a ética, mas sim fazer com que as coisas sejam iguais dos dois lados do tabuleiro. O que me interessa é o que faz a diferença entre a experiência e a não-experiência nessas áreas, e você está mais interessado em distinguir estes dois domínios.

P: Apenas se eles precisarem ser distinguidos. Falando em especialidade, parece haver um modo correto para se jogar xadrez, a saber, aquele pelo qual se ganha, ao passo que me parece muito mais difícil definir especialidade ética desta maneira. Há um modo correto de ser um perito em ética?

HD: Aristóteles diz que apenas o homem bom pode reconhecer quais ações são boas e quais não são. Ser bom em ética é fazer o que é considerado bom em sua cultura, ou seja, o que as pessoas de sua cultura assim consideram na condição de pessoas sábias, pessoas que sabem o que é bom, que consideram aquilo que é feito como sendo a coisa certa. Há um certo tipo de circularidade nisso. Assim sendo, é diferente do jogo de xadrez. 
SD: Não, o xadrez não é totalmente diferente disso. Contanto que haja um ganhador ou um perdedor em um jogo de xadrez. Mas se você quer saber se uma determinada jogada foi boa ou não, basta perguntar a um jogador de xadrez experiente se aquela foi a jogada que o fez perder o jogo ou se ela foi excelente, e alguma outra jogada causou a derrota. Portanto, tanto no xadrez quanto na ética é muito difícil dizer que há uma definição objetiva que estabeleça se uma determinada jogada em uma determinada posição é boa ou ruim.

P: Fazer a jogada certa é fazer a jogada que as pessoas que são consideradas as melhores fariam naquela situação?

SD: Exatamente, e os especialistas em xadrez o vêem como uma coisa social. $\mathrm{O}$ que é considerado como sendo a jogada certa em xadrez só o é devido à história do jogo de xadrez. Quando os computadores jogam xadrez, de vez em quando fazem jogadas que são melhores do que a jogada aceita - melhor mesmo do que um mestre poderia fazer - porque a história social do xadrez faz com que nem mesmo um mestre enxergue todas as possibilidades.

\section{P: Então, o que significa "melhor"?}

SD: Um lance do computador seria considerado melhor do que o de um grande e reconhecido mestre se, após o jogo, peritos concordassem que a jogada do computador levou a uma situação mais desejável.

P: Ainda assim, parece-me que há um criténio mais rigoroso no xadrez do que na ética para avaliar se uma decisão é válida, não é mesmo?

SD: Há algo diferente, é obvio, no sentido de que no final do jogo você tem um resultado do jogo. Mas supondo que no mundo real houvesse um Deus e um julgamento após a vida, e que as pessoas vivas soubessem qual seria o julgamento de suas vidas. Isso teria muito efeito sobre a ética? Não. Especialistas em ciências humanas teriam que avaliar subjetivamente quais atos durante sua vida levaram àquele julgamento.

P: A questão aqui é o feedback? Você tem um tipo diferente de feedback numa situação de jogo de xadrez e numa situação que envolve a tomada de uma decisão ética? 
HD: Stuart acha que não. Em ambos os casos você tem o feedback de alguém que é uma autoridade reconhecida e capaz de dizer qual é e qual não é a coisa certa a fazer, em qualquer jogada específica, em qualquer situação específica.

SD: Você pode perder o jogo com 99\% de jogadas inteligentes e, se não for suficientemente bom, não saberá qual delas o fez perder o jogo. Então um grande mestre vem e diz, você perdeu por isso e por aquilo, e aponta para uma certa jogada, mas esta pessoa é apenas inteligente e não consegue explicar porque diz aquilo, além de poder não estar certo, embora geralmente esteja.

HD: A única diferença que vejo é que eu não sei como as pessoas sábias da cultura são selecionadas ou auto-selecionadas, enquanto que as pessoas que no xadrez têm o direito de manifestar opiniões sensatas são pessoas que têm alta qualificação no jogo, e isto é objetivo. Seja lá como for a seleção das pessoas sábias da cultura, esta não é objetiva como é a seleção no xadrez.

SD: Não estou certo que seja verdade que entre as várias centenas de especialistas, o melhor jogador do mundo seria a pessoa mais indicada para dizer às outras pessoas onde elas erraram e o porquê. Certamente os melhores instrutores não são os melhores jogadores.

HD: Entendo agora que haja dois padrões diferentes no nosso conceito de sabedoria na ética. Em nosso trabalho não tratamos do feedback que vem da aprovação ou desaprovação das pessoas sábias. Falamos do feedback que vem se você se sente mal ou não quanto à sua atitude, se você a lamenta ou está orgulhoso dela. Se o feedback principal está em você se lamentar ou não, talvez aquilo que as pessoas sábias pensem não seja realmente importante. Concordamos com Aristóteles em nosso trabalho que se você quiser saber o que fazer, pergunte a um homem velho e sábio. Mas também dizemos, o que parece ser uma contradição, que duas situações nunca são semelhantes, e a maneira pela qual você entrou na situação, suas experiências passadas e em que ordem você as teve é que vai determinar, por assim dizer, qual a coisa certa a fazer. Então, qual é a vantagem do homem velho e sábio? Ele apenas poderá lhe dizer, de acordo com o que pensa da situação, o que ele faria. Talvez ele possa servir de tutor enquanto você ainda é um principiante.

SD: Supondo que a situação seja muito simplória, do tipo "devo entregar meu pai como assassino", como no diálogo Eutífron de Platão, de forma que a outra pessoa possa entendê-la, então parece-me irrelevante o fato de sua experiência levar a pensar que você deve fazer o que deve fazer, comparado com o que uma pessoa com uma experiência bem maior acha que deveria ser feito. 
HD: Mas isto também não estaria errado em relação à história de Eutífron? Usando o modelo de Carol Gilligan, um homem diria, sim, a questão quanto a se Eutífron entregaria seu pai, é simplesmente uma questão de princípios, alguém entregaria seu pai por matar um escravo? Mas, às mulheres perguntariam, o pai maltratava freqüentemente seus escravos? Foi por acidente que ele deixou seu escravo no fosso para morrer ou ele deixou outros escravos morrerem? E começará parecer que não é absolutamente uma questão de princípios, mas o que fazer com esse determinado pai, que teve um determinado tipo de passado.

SD: Sim, pessoas velhas e sábias não deveriam ter simplesmente princípios, mas sim o maior número possível de informações de base.

\section{P: Por que a situação tem que ser simples?}

SD: Se você não consegue articular suficientemente uma situação ou responder perguntas sobre ela, então não pode pedir conselhos a uma pessoa velha e sábia. Talvez a situação não tenha que ser simples, mas acho que não pode ser complicada ou matizada demais para que seja articulada adequadamente, porque, neste caso, você não poderá ir a uma pessoa sábia fazer perguntas, obter respostas e investigar a situação.

P: Como eles se inter-relacionam, i.e., seu próprio sentimento de insatisfação ou satisfação diante de um acontecimento e o feedback de uma pessoa sábia diante do acontecimento? Esta parece ser uma tensão não resolvida?

SD: Acho que estou dando prioridade ao feedback da pessoa sábia...

HD: ...por basear-se em suas insatisfações passadas bem como na auto-aprovação e na soma total de várias delas...

SD: ...que você dificilmente conseguirá ter, mas se pudesse obtê-las e ouvi-las de uma maneira envolvida e internalizada que realmente o afetasse...

HD: ...e se ele pudesse pensar sobre as insatisfações e satisfações que foram relevantes para a situação real em que você se encontra...

SD: ...então você aperfeiçoaria seu desempenho no futuro mais do que apenas observando se, com base em sua experiência, você ficaria insatisfeito ou não.

HD: O problema é que as suas próprias insatisfações e satisfações têm que ser aculturadas porque um mesmo acontecimento poderia em uma cultura ser motivo de 
insatisfação enquanto que em outra poderia ser motivo de satisfação. E apenas uma pessoa sábia que cresceu nessa cultura poderia ajudá-lo a desenvolver a sensibilidade correta, uma noção tipicamente aristotélica.

P: Então vocês desejam buscar o feedback das pessoas mais expenientes para tornar-se um perito ético, mas, ao mesmo tempo, você parece estar dizendo que esse tipo de feedback raramente está disponível?

SD: Se não há feedback algum, não vejo como você poderia adquirir habilidade ética. Se você não tem feedback da cultura ao seu redor, não vejo como aprendê-la.

HD: Você não cresceria para ser ético emı nenhum modo ético de qualquer cultura em particular.

SD: Assim, a maior parte da aprendizagem é, de alguma forma, feedback, feedback indireto da cultura ao seu redor. Penso que, para haver uma aprendizagem mais rápida, seria preferível se você pudesse obter feedback de uma pessoa velha e sábia o tempo todo, o que nem sempre é possível.

P: Agora, voltando à questão oniginal, o tipo de aprendizagem e feedback de que estamos falando é o mesmo na techne e na phronesis, ou, se quiser usar os termos de Weber, é o mesmo na racionalidade instrumental e na racionalidade de valor (Wertrationalität)?

HD: Eu realmente não acredito nessa distinção. Racionalidade de valor é um modo estranho de se falar sobre ética. Não é como Aristóteles a trataria, e Heidegger pensa que "valor" é apenas mais um termo instrumental porque objetiva totalmente a ação moral. O que é um valor? Um valor é apenas uma outra qualidade dos bons atos, que os bons atos têm e que os maus atos não têm, mas atos não surgem com qualidades como esta, de acordo com o que pensamos. Em nossa história, e na de Aristóteles também, penso que o mesmo ato em situações diferentes, realizado por pessoas com experiências diferentes e assim por diante, poderia ou não ser bom ou ruim, e portanto todo o vocabulário de valor está errado, e a racionalidade de valor não é importante. Racionalidade instrumental versus racionalidade de valor, aonde se pretende chegar com isso? Eu diria que o que importa, e novamente aposto que isto está próximo a Aristóteles, é tratar habilmente com coisas versus tratar habilmente com pessoas. Não são dois tipos de racionalidade, e é um mau sinal se Weber e Habermas as consideram assim. Heidegger diz, finalizando uma piada, depois desta longa discussão sobre valores: "Ninguém morre por valores". Valores são apenas propriedades objetivas sem sentido. As pessoas morrem por seus compromissos e ideais. De acordo com Weber e Habermas, as pessoas usam a razão instrumental para 
alcançar seus propósitos. A crítica à racionalidade instrumental só faz sentido quando se opõe a uma racionalidade boa, o que significa determinar quais deveriam ser os propósitos das pessoas. A racionalidade instrumental define-se, então, como uma tentativa de realização de propósitos em oposição a uma tentativa de decidir quais propósitos realizar. Mas uma vez que Stuart e eu não acreditamos que, de maneira geral, haja qualquer meio racional para descobrir, em detalhe, quais são os propósitos certos a se realizar, mas apenas sabedoria, não opomos nenhum tipo de alta racionalidade à racionalidade instrumental. Voltemos agora a Aristóteles, que percebeu que as pessoas estão sempre tentando realizar propósitos. Aristóteles é zweckrationalität do começo ao fim. Na vida você busca felicidade, quando está construindo um barco você tenta conseguir que ele flutue. Você sempre está tentando realizar algo.

P: Antes falávamos de contexto dependente e específico versus controle e legislação na relação com as práticas marginais. Você argumentava que legislar em defesa de tais práticas é bastante problemático e que o respeito pelo específico e pela dependência contextual é antitético em relação ao controle estatal. Vamos voltar.a essa questão, agora sob a luz do conceito de phronesis. Aristóteles diz, "A Sabedoria [Phronesis], no que se refere ao estado, tem dois aspectos: um, controlador e direto, é a ciência legislativa; o outro, que trata de circunstâncias específicas (...) é prático e deliberativo".(Aristóteles, 1966) Parece que Aristóteles reforça tanto o coletivo como o particular, o controle e a circunstância, o poder soberano e o poder individual em seu conceito de phronesis. E me parece que a partir de Aristóteles desenvolveu-se, na filosofia e no pensamento social, uma divisão infeliz, para não dizer trágica, de duas tradições separadas, cada uma representando um dos dois lados por ele salientados. Uma tradição se desenvolveu a partir de Sócrates e Platão via Hobbes e Kant até chegar a Habermas, dando ênfase, é claro, ao primeiro dos dois lados. A outra, talvez parcialmente aristotélica e parcialmente sofista na origem, se desenvolveu via Maquiavel até Nietzsche, Foucault e Derrida e talvez até você. Atualmente as duas tradições vivem vidas separadas, com exceção dos ataques tipicamente retóricos e ocasionais dos pensadores de uma tradição para os pensadores da outra, sendo a crítica feita por Habermas a Foucault e Dernida em The Philosophical Discourse on Modernity um caso em discussão. Na minha interpretação, Aristóteles insistiu, no entanto, que o que interessa para a compreensão e para a práxis é o que acontece quando os dois lados agora separados se interseccionam, e que este ponto de intersecção é o símbolo geométrico, por assim dizer, da atividade "prhonetica" apropriada.

HD: Isso parece promissor. Nós tendemos a deixar o lado legislativo para Habermas. Se a habilidade consiste em responder a situações únicas, então, o universal e o imparcial não se enquadrām aí. Você não fará necessariamente a mesma coisa na mesma situação como outra pessoa, e mesmo assim ambas as respostas 
podem estar moralmente corretas. É possível que nem mesmo você faça a mesma coisa na mesma situação em uma próxima vez. É o que ocorre com a sabedoria. Mas a legislação tem que ser universal, imparcial e justa. Pelo menos é o que nossa tradição julga. E uma vez que Stuart e eu não temos nada a dizer sobre o universal, o imparcial e o justo - não até agora - nós deixamos isso para os teóricos da moral. Assim, estamos nos movendo em dois caminhos diferentes, e não vejo como juntá-los. Há toda uma história em Aristóteles de que existem formas universais nas coisas, e de que existem princípios básicos, e de que há bases racionais. Aristóteles pode combiná-los todos, porque ele aceita tudo: a lei natural, a base racional, a habilidade e tudo mais. É uma questão interessante saber se alguém poderia ser um aristotélico pós-metafísico e manter juntas estas coisas.

P: Como exemplo, consideremos uma pessoa, ou, de preferência, uma instituição - o ombudsman - que foi desenvolvido para operar onde o específico enfrenta o coletivo, onde as circunstâncias enfrentam o controle, onde o indivíduo e, na verdade, as pessoas ou organizações marginais enfrentam o sistema administrativo-legal. $\mathrm{Na}$ Escandinávia, onde tal instituição se originou, o ombudsman é uma figura nacional indicada pelo parlamento para supervisionar a administração municipal e estadual. A instituição ombudsman foi estabelecida devido à preocupação com os direitos do indivíduo diante de um sistema administrativo forte e em ampliação. Existe um ombudsman para todo o país na Dinamarca, e creio que dois na Suécia. Comparada a outras instituições de supervisão, há um elemento pessoal substancial na instituição ombudsman e, na prática, um extenso campo para mudanças de acordo com as tendências sociais de mudança. Como pessoa, o ombudsman é escolhido de acordo com o modelo do velho sábio anistótélico, i.e., uma pessoa prudente, de reputação pública imaculada, com larga experiência em questões de administração legal e nas formas como estas se relacionam com os indivíduos. O ombudsman trabalha com base em casos específicos e é uma infusão, no sistema administrativo-legal baseado em regras, de alguém que, com autoridade, pode exercer um julgamento prudente quanto aos diferentes procedimentos de caso para caso. É interessante notar neste contexto que o ombudsman, mais freqüentemente do que os tribunais, tenta contornar casos na lei administrativa, i.e., casos que requerem uma grande quantidade de julgamento. No geral, o ombudsman julga, em certo sentido, casos que os tribunais raramente, ou nunca, julgam. Além disso, o domínio dos casos tratados pelo ombudsman é geralmente maior do que o domínio dos casos julgados nos tribunais. Em suma, o ombudsman fornece o feedback em relação aos procedimentos e mostra como eles poderiam ser modificados para funcionar melhor.

HD: Há duas histórias diferentes, então, que dizem respeito ao papel do ombudsperson. Uma, que pode ser fascinante, é a de que o ombudsperson vê como a legislação-universal, em casos particulares, causa o oposto do que se quer causar, 
no espírito da lei, e chama a atenção dos legisladores quanto a isto para que possam reformular a lei. Esta é a sua história. Ao passo que, neste país, o ombudsperson é simplesmente alguém que defende os indivíduos que foram apanhados pela burocracia de tal forma que seu caso particular não pôde ser ouvido.

SD: O ombudsman aqui assegura que as regras e os princípios sejam adequadamente implementados. O ombudsman conhece as regras e princípios e sabe como implementá-los.

HD: Você vai ao ombudsman exigir seus direitos.

SD: Não há sabedoria envolvida.

HD: Você não vai procurá-lo somente quando o sistema sucumbe em virtude do modo como o universal se encaixa no particular. É só alguém ser apanhado pela máquina de algum modo infeliz, e o ombudsman é chamado para resgatá-lo.

P: Então não se pressupõe que o ombudsman nos Estados Unidos questione e desenvolva o processo administrativo-legal?

HD: Acho que não.

P: Na prática, esse é, em parte, o papel dele ou dela na Escandinávia. Admite-se, no sistema político-parlamentar, que a máquina administrativa-legal não pode, por si só, ser responsável pela resolução de todos os problemas, sendo que, na verdade, ela poderá até mesmo vir a criar problemas. Assim sendo, a monitoração feita por esses "velhos sábios" é tida como necessánia.

HD: No meu entendimento, ele é sábio pelo fato de, valendo-se de determinados universais legais, sugerir como mudar esses universais de forma a torná-los ajustáveis àquilo que uma pessoa sábia faria nos casos específicos. Parece que ele ajuda o legislativo a obter princípios universais a partir da sabedoria. Coloquei dessa forma porque sei que Stuart ficará preocupado com isso, uma vez que parece uma tarefa impossível.

SD: Bem, ele não está articulando princípios, ao que parece. Ele está julgando casos que podem se destacar como precedentes. Isto é um pouco melhor do que articular princípios. 
HD: Sim, isso é melhor, mas se suas decisões voltam aos legisladores, alguém tem que se mover em direção aos princípios. E nesse movimento eles perderão algo importante.

SD: As decisões do ombudsman voltam para os legisladores?

P: As decisões são apresentadas aos legisladores, mas o ombudsman não tem nenhuma autoridade para impor mudanças às leis. Suas decisões são balizas que ganham influência pelo respeito geral e pelo prestígio associado à instituição do ombudsman. A interpretação das leis em vigor, e, desse modo, em prática, pode mudar baseada nas decisões em relação a casos e procedimentos individuais do ombudsman?

SD: De certa forma é parecido com o que a Corte Suprema faz neste país. Normalmente ela não recorre a ninguém para mudar nada. Suas decisões mudam as coisas por si próprias.

HD: Então isto traz o universal, que nunca captará de forma completa as intuições sobre o que é certo no particular, mais próximo ao particular, estabelecendo precedentes sobre como aplicar os universais ao particular. Isto é bom. Vocês têm direito consuetudinário ou jurisprudência na Escandinávia?

\section{P: Temos as duas.}

HD: As leis de código tentam tanto quanto possível explicitar tudo, esse é o sistema napoleônico. O direito inglês não tenta explicitar tudo, pois, sabe que isso é impossível. Então, quando você discute um caso, você discute se esse caso é mais ou menos semelhante aos casos anteriores onde as decisões já foram tomadas. A questão é com qual caso este é mais parecido, e, ao encontrar este caso, deve-se tomar a decisão que já foi tomada. Agora, o que isto significa? Bem, o direito consuetudinário é certamente bem melhor para o caso do modelo de habilidades, porque preserva muito da intuição ao considerar o caso corrente como semelhante a alguns casos anteriores, com os quais vocêjá sabe lidar. De forma que você não precisa de um ombudsperson no sistema inglês, já que aquilo que o juiz está fazendo o tempo todo é tentar ver como aplicar a lei com base em precedentes. Talvez seja por isso que o ombudsman tenha um papel mais importante em seu sistema do que no nosso. Mas eu ainda acho que esse é um bom exemplo. Entretanto, o verdadeiro problema em relação a juntar os dois lados de Aristóteles consiste em saber o que fazer quando se tem que criar a legislação, porque então é preciso fazer algo universal. O ombudsman, direta ou indiretamente, dá a opinião ao poder legislativo para que este faça uma legislação universal. 
P: O poder legislativo sabe em primeira mão que suas leis não funcionarão sem monitoração. Daí a existência do ombudsman.

HD: Então há um tipo de ciclo?

P: Exatamente. Na realidade você precisa dos dois e não existe um sem o outro. Então, talvez este exemplo possa ser usado para ilustrar que não é necessário aceitar a divisão entre o particular e a legislação da qual falamos. Aborrece-me ter que deixar a legislação, como vocês parecem fazer, para a tradição Platão-Hobbes-Kant-Habermas, i.e., para os racionalistas. A legislação é importante demais para isso. E acho que a tradição do particular, de caso e de contexto, tem muito o que contribuir com a legislação para anulá-la dessa forma. Por fim, acho que Aristóteles insistiu nessa idéia, mas foi esquecido ou ignorado pelas duas tradições.

HD: Gosto disso.

P: Recentemente eu estava andando por Copenhague com um professor americano da área de planejamento. Andamos de um lado a outro de Copenhague por belos parques, discutindo a relevância do que vocês têm escrito para o planejamento da cidade, do meio ambiente etc. A princípio, este professor rejeitou qualquer relevância, devido à natureza particularista das idéias que vocês apresentam.

HD: É o que eu teria dito também.

P: Então eu disse, olhe para todas as práticas não racionalizadas ou práticas marginais, começando exatamente aqui onde estamos andando: piqueniques familiares, crianças brincando, pessoas olhando os cisnes e alimentando os patos, nudistas tomando banho de sol, pessoas espiando os banhistas nus, pipas voando, pessoas olhando as plantas nos jardins botânicos, joggers - eu sei que você pode não querer chamar o jogging de prática marginal - e pessoas saindo para caminhar. Você pode nomear as primeiras cinqüenta práticas marginais diferentes, todas acontecendo nesses parques num dia de sol, mas os próprios parques, servindo como ponto de partida para tudo isso, tornando tudo isso possível - considere o simples fato de um parque estar ligado ao próximo por toda Copenhague -, são o resultado de uma legislação e planejamento racionais. Novamente, isto me parece ser um exemplo de que os dois lados não estão separados, mas estão interagindo, cada um dando ao outro conteúdo, de fato, qualidade.

HD: Sim, acho que a ligação crucial que você faz sobre a legislação e esses dois exemplos seria algo assim: no quadro racionalista, a legislação está tentando captar a universalidade e a justiça comum; idealmente ela deveria torná-las o mais próximo 
possível; quanto mais ela aproximar a universalidade e a justiça comum tanto melhor. Isso significa Rawls, o liberalismo etc. O que estamos dizendo é que, infelizmente, a legislação é forçada a pensar em termos de universalidade e justiça. Mas há algo intrinsecamente errado com isto. O estabelecimento do ombudsman de forma a fazê-lo interagir com o sistema administrativo-legal é reconhecer esse aspecto. O objetivo deixa de ser a universalidade e a justiça comum, que passam a ser realmente irrelevantes para uma situação fora do comum, de forma que você tem que consertar constantemente esta universalidade e justiça comum. Este é um modo muito diferente de se encarar a legislação. O que é importante ter em mente - importante porque é muito difícil se acostumar a isso - é que tanto a universalidade quanto a justiça comum não são virtudes positivas, como se fossem um tipo de posição de retrocesso quando não se tem a sabedoria. Isto faz tudo parecer mais diferente do que é para pessoas como Habermas e para os kantianos. Mas posso considerar a sua colocação de que a legislação e a justiça comum são importantes demais para que não tenhamos uma opinião a seu respeito, simplesmente passando-as aos racionalistas, como fizemos em nosso último texto. Gostaria de retomar isso agora e dizer que sim, precisamos de legislação, universalidade e justiça comum, mas não porque a universalidade e a justiça comum são outros princípios morais igualmente importantes. Precisamos deles porque não se pode legislar sobre todo o caso específico; ainda assim, seria melhor se pudéssemos; pois perde-se algo quando não podemos fazê-lo.

\section{P: Comunidade parece ser a palavra mágica aqui.}

HD: Certo. Se há universalidade, ela é a sensibilidade compartilhada e o senso de responsabilidade que as pessoas têm ou não têm. É com isso que pensadores como Robert Bellah e Charles Taylor estão preocupados. As pessoas querem cada vez mais dizer que a primeira coisa a resolver é como superar o individualismo - cada um tentando maximizar a sua própria felicidade, sem se preocupar com o resto. Isso é um problema tão grande que pode-se ficar atolado nele. Não é problema nosso, portanto não estamos atolados nele. O que quero dizer é que não é nosso problema filosófico, é o problema pessoal de todo mundo.

P: Mais uma vez eu poderia ver esta posição como uma causa real da ansiedade cartesiana em algumas partes, e muitas pessoas, incluindo provavelmente Habermas de novo, veriam inegavelmente tendências elitistas e antidemocráticas tanto no seu modelo quanto na ênfase em phronesis. Como vocês vêem sua posição em relação à democracia e à ética democrática?

HD: Quando eu estava em Frankfurt e apresentei o modelo de cinco estágios de habilidades, Habermas disse, "Você está falando sobre habilidades como martelar e jogar xadrez, mas o que você realmente quer fazer é enfraquecer a sociedade 
ocidental". Eu disse "Você está certo, esse é exatamente o meu objetivo". Começa-se com uma descrição simples sobre perícia e acaba-se falando como acabamos de fazer. Os racionalistas dizem que é preciso ser capaz de articular os princípios subjacentes a qualquer decisão racional. Nós dizemos não, a menos que você os insira em sua definição de racional. Se você quer dizer que qualquer um deve ser capaz de articular os princípios subjacentes a uma decisão que tiver tomado, e que essa decisão se revela ser uma boa decisão com base em experiências passadas e, talvez, até mesmo a melhor decisão, como a de se terminar um jogo ou de se fazer uma autópsia, então é falso - um erro que começa com Sócrates e Platão - sustentar que tal decisão faz alguém articular seus princípios. O racionalista contra-argumenta que, se você não puder fazer isso, a discussão democrática das decisões, que requer a decisão sobre a aceitação ou não dos princípios sobre os quais essas decisões são tomadas, é impossível. Nós responderíamos, você tem uma escolha. Ou você reestrutura sua idéia de discussão democrática em torno de pessoas contando histórias e vendo qual narrativa é mais aceitável ou você pode optar por decisões competentes ao invés de especializadas e manter sua análise democrática.

Ao contar histórias, as pessoas, incluindo os políticos, usam retórica, mas mesmo a retórica não é arbitrária, porque algumas retóricas funcionam e outras não, como diria alguém como Foucault. Se sua retórica funciona - se as pessoas usam seu vocabulário e a sua história - isso significa que você está falando no interesse das pessoas sobre algo que realmente as interessa. O teste para saber se você está em alguma coisa certa é ver se ela ressoa junto às pessoas. É claro que os cabelos de Habermas imediatamente ficam de pé quando ele se lembra de Hitler. A retórica de Hitler ressoou junto àquilo que o povo alemão queria, e isso é assustador. Não se pode descartar isto facilmente; o que se quer é ser capaz de, se não controlar os políticos, pelo menos ser capaz de dizer que a retórica desse homem é perigosa.

P: O que vocês vêem como um baluarte contra este tipo de retórica perigosa?

HD: Creio que a forma atual de se colocar a questão no cenário filosófico é a questão de se estar do lado da moralität ou sittlichkeit, para usar os termos de Hegel. Estas são as duas alternativas - o certo versus o bom. Sittlichkeit são os costumes que as pessoas compartilham, que lhes dá o senso de prioridade de bens, por exemplo, e o que são os problemas correntes. E o único baluarte contra Hitler, se esta for a história certa, seria a sittlichkeit do povo alemão. Eles aceitaram a retórica perigosa sobre a superioridade da Alemanha, mas as práticas preservadas das tradições gregas e cristãs resistiram ao assassinato de seis milhões de pessoas. Quando os alemães estavam matando os judeus e atacando a Polônia, não estavam fazendo isso em nome do senso comum moral da Alemanha. A Alemanha era um estado policial e toda discussão fora paralisada, toda a resistência fora trancafiada ou assassinada, e muitas pessoas nem 
mesmo sabiam o que estava acontecendo. Se pode haver uma sociedade na qual a maioria apoiasse livremente essas atrocidades, eu não saberia o que dizer.

\section{P: Nós conhecemos tal sociedade?}

HD: Não, não creio, mas se houvesse tais práticas compartilhadas, dizer a eles que a sua sociedade estava condenada pelos princípios morais universais não os deteria.

P: Você mencionou anteriormente o fato de Habermas ter dito que você quer enfraquecer a sociedade ocidental com o modelo de cinco estágios, e você respondeu que ele está certo. Que tipo de sociedade você gostaria de ver surgir da atual sociedade ocidental?

HD: Não quero uma sociedade que vê o homem como um animal racional, ou mesmo que encontre os primeiros princípios ou entre no tipo de ansiedade em relação ao relativismo de que falamos, mas de fato uma sociedade que possa viver com a idéia de que tudo o que temos é nossa sittlichkeit, nossas práticas, de forma que essas pessoas concordarão com o que é mais humano e assim preservarão mais do que o que você chamaria de dignidade humana. Tudo isso é uma prática relacionada e além dos princípios.

\section{Referências bibliográficas}

ARISTÓTELES. The Nicomachean Ethics. Harmondsworth: Penguin Classics, London: Oxford University Press, 1966. 1141 b8- 27.

BENNER, P. The primacy of caring: stress and coping in health and illness. Menho Park: Addison/Wesley, 1989.

BORGMANN, A. Technology and the character of contemporany life: a philosophical inquiry. Chicago: University of Chicago, 1984.

DREYFUS, H., DREYFUS, S. Towards a phenomenology of ethical expertise. (No prelo)

DREYFUS, H., DREYFUS, S., ATHANASIOU, T. Mind over machine: the power of human intuition and expertise in the era of the computer. Rev. Ed. New York: Free Press, 1988. PIRSING, R. M. Zen e a arte de manutenção de motocicletas: uma investigação de valores. Trad. Celia C. Cavalcanti. Rio de Janeiro: Paz e Terra, 1984. Zen and the art of motorcycle maintenance. New York: Bantan, 1974. 